\title{
Integrating Entrepreneurship Skills Across Radio, Television and Electronic Work Trade Curriculum in Technical Colleges in North- Western Nigeria
}

\author{
Halliru Shuaibu, Yusri bin Kamin, Rabiu Haruna
}

\begin{abstract}
This qualitative study explores the integration of entrepreneurship skills (ES) across the curriculum of Radio, Television and Electronic Work trade curriculum in NorthWestern Nigeria. Based on the perceptions of two strata of stakeholders (entrepreneurship teachers and Radio, Television and Electronic Work curriculum planners), the feasibility and desirability of embedding entrepreneurship skills across Radio, Television and Electronic Work trade curriculum in selected technical colleges were analysed after conducting a preliminary study. Document analysis and in-depth interview were used as the methods for data collection. The findings show that crosscurricula entrepreneurship skills remain non-existent in technical colleges in Nigeria, largely because its implementation is not captured in technical disciplines. However, the study points out the importance of embedding entrepreneurship skills into Radio, Television and Electronic Work trade curriculum for wealth creation and employment generation among technical college graduates. In addition, the five stages of integrating curriculum adopted from the lifelong learning model were briefly discussed. The components of entrepreneurship skills discovered in the study included: entrepreneurial awareness, starting and operating a business, business ideas and opportunities, characteristics or traits of entrepreneurs, and self and paid employment among others. Donor support and retraining needs of trade teachers were also highlighted as complementary factors for enhancing the implementation of embedded curriculum in Nigeria.
\end{abstract}

Keywords: Integrating entrepreneurship skills; Radio, Television and Electronic Work trade curriculum; Nigerian technical colleges

\section{INTRODUCTION}

Young people require entrepreneurship skills (ES) in order to successfully create new jobs or set up and sustain small enterprises in every society across the world. Therefore, strategic measures are needed to encourage young people considering self-employment and paidemployment as an occupation. A feasible strategy is to

Revised Manuscript Received on April 19, 2019.

Halliru Shuaibu, Department of Technical and Engineering Education, Universiti Teknologi Malaysia, School of Education, Faculty of Social Sciences and Humanities, Johor Bahru, Malaysia.

Department of Electrical/Electronics Technology Education, Federal College of Education (Technical) Bichi, Kano-Nigeria.

Yusri Bin Kamin, Department of Technical and Engineering Education, Universiti Teknologi Malaysia/ School of Education/ Faculty of Social Sciences and Humanities, Johor Bahru, Malaysia.

Rabiu Haruna, Department of Technical and Engineering Education, Universiti Teknologi Malaysia/ School of Education/ Faculty of Social Sciences and Humanities, Johor Bahru, Malaysia.

Department of Electrical/Electronics Technology Education, Federal College of Education (Technical) Bichi, Kano-Nigeria. integrate and implement entrepreneurship skills into technical colleges' curricula. This idea is supported by researchers like [1] who conducted a study and reported that entrepreneurship skills should be embedded in curricula across all educational level and types so as to enhance socioeconomic development of individuals and nations.

Figure 1 shows an illustration of six countries studied, where entrepreneurship skills integration into school based curricula were conducted and reported in the work of [2] in the year 2013. The affected countries included Finland, Sweden, and Austria from Europe. While Jordan, Lebanon, and Morocco from Arabic speaking countries. This is done in order to explore and discover how and why integration of entrepreneurship skills into other core curricula is practiced in other countries.

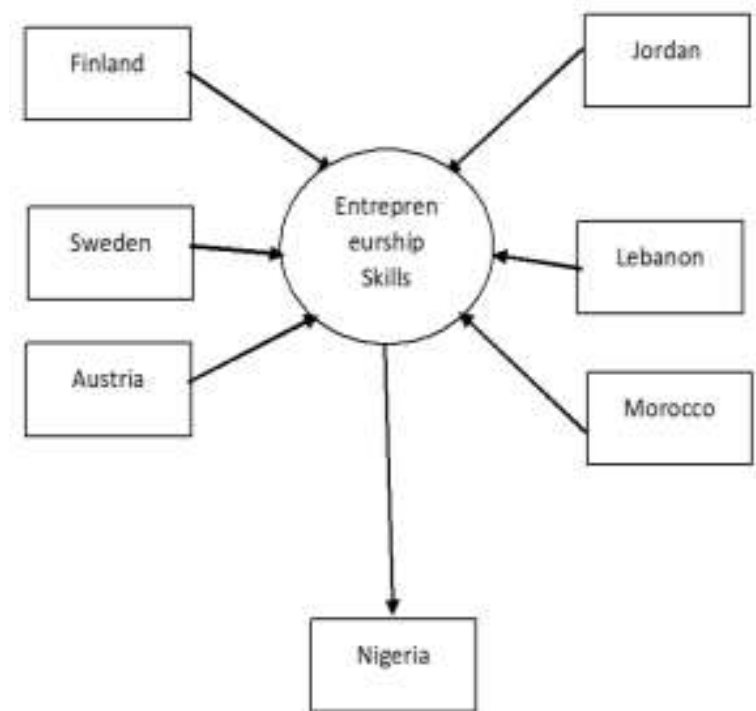

Fig. 1: Countries Surveyed for Curriculum Integration Approach.

Source: Hatak \& Reiner, (2013).

The findings from the studies on integrating entrepreneurship skills as an integral part of curricula indicate changes on several levels from the six countries First, changes were effected in teaching and evaluation methods (for instance, experiential learning, writing feasibility report, and process evaluation) as a requirement for imparting functional education to students. Second, the 
educational contexts were modified (for example, introducing resource person talk in schools). Third, paradigm shifts of attitude needed from government was obtained because government does not only provide funds but also control the access and quality of education.

In the context of education, curriculum integration has been approached by using several models. For instance, [3] reported that educators can begin with an exploration within single disciplines using the fragmented, connected, and nested models. Other models that integrate curriculum across several disciplines included the sequenced, shared, webbed, threaded, and integrated models. The continuum ends with models that operate within learners themselves (the immersed model) and finally across networks of learners (the network model). This study investigated the integration of entrepreneurship skills across Radio, Television and Electronic Work trade curriculum in north western States of Nigeria, using perceptions of stakeholders. Entrepreneurship teachers from commercial colleges and Radio, Television and Electronic Work trade curriculum planners were the stakeholders used in this study.

\section{PROBLEM BACKGROUND}

Nigeria is an oil-based economy and the biggest black nation in Africa having population of 193.88 million, GDP of 3.758 billion USD, and inflation rate of $13.5 \%$ per annum [4]. [5] in the National Policy on Education (NPE) spelt out training (TVET) shall be to: (a) Provide trained manpower in applied sciences, technology and business particularly at craft, advance craft and technical level; (b) Provide the technical knowledge and vocational skills necessary for agricultural, commercial and economic development; and (c) Give training and impart the necessary skills to individuals for self-reliance economically. In pursuant of the above goals the main features of the curricula activities for technical colleges shall be structured in foundation and trade modules. [5] also stated that the curriculum for each trade shall contained five components, namely: (a) General education, (b) Theory and related courses, (c) Workshop practice, (d) Industrial training (production work), and (e) Entrepreneurial training. The researchers observed that contrary to the provision of the National Policy on Education, the National Board for Technical Education (NBTE) curriculum being used in Radio, Television and Electronic Work trade in technical colleges does not capture entrepreneurship training; though, stand-alone entrepreneurship curriculum exists in business education. This indicates a weakness or gap in the composition of Radio, Television and Electronic Work curriculum in technical colleges of Nigeria.

Curriculum, according to [6] , can be viewed as a course of study especially in schools for attaining certain goals. Curriculum is an evolving thing, that is, it is always in the making, being more in the nature of a process than a finished product. While it tells us what to teach, it does much more than to draw the boundaries of academic subjects and helps to identify appropriate methods of teaching-learning and stages at which various ideas can be introduced. Curriculum includes the totality of experiences, which the learners receive through manifold activities that that the goals of technical and vocational education and

takes place in a college, classroom, library, laboratory, workshops, and playgrounds. In essence, the whole life of the college becomes the curriculum, which can affect the life of students at every point and helps them to develop a balanced personality. Technical education curricula in Nigeria, suffers from the gap between its contents and the living experiences of students. Technical education curricula, ideally, must prepare students to face challenges in the world of work [7] and [8]). For this purpose, entrepreneurship skills and technical skills need to be intimately linked and integrated.

Thus, in Nigeria, in addition to inculcating functional technical skills, literacy and numeracy in school leavers, education is expected to address the challenges of youths' restlessness, poverty and unemployment by promoting the specific goals of value re-orientation, wealth creation, poverty eradication and employment generation. Among the reasons attributed to youths' restlessness, poverty and unemployment in Nigeria was lack of relevant work skills and competencies in young school leavers due to absence of effective entrepreneurial skills in schools' curricula that will prepare them for 21st century world of work [9] and [10] . Hence, the present study discussed stages to be assumed for entrepreneurial start up and development as well as determined the perceptions of stakeholders for integrating entrepreneurship skills across Radio, Television and Electronic Work trade curriculum with hope of improvement in skills acquisition by the students.

\section{PROBLEM STATEMENT}

The rapid changes in all walks of life is growing throughout the globe because new technologies are coming into existence, creating stimulating opportunities for people willing to take risks and take advantage of these opportunities. This makes career paths to become interdisciplinary. Learners need to bring knowledge up-todate and transfer it to newer contexts. This requires an enterprising mind-set that will consider challenges as opportunities, not difficulties. The revolutions in employment circles created a need to promote entrepreneurship skills among students, such as, independent and creative thinking, problem solving, selfawareness, coping with stress, and decision making. This calls for rethinking in selecting and delivering instructional content and integration of new sources of information for developing professional competence that will yield socioeconomic development [6]

In the context of Nigeria, many factors adversely affected the socio-economic well-being of the country. For instance, the problem of youths' unemployment, increase in population, spontaneous rural-urban migration, political conflicts, declining quality of technical graduates from colleges due to deterioration in teaching and physical facilities, inadequate funding, and ineffective curricular for teaching the students [7] . [7] further opined that government in Nigeria approach the problems of youths' restlessness through vocationalization of education systems. 
In spite of this effort, unemployment still persists even among those with technical skills largely due to absence or poor possession of entrepreneurship skills in school curricula. This implies that there is a sharp decline in the required skills of technical graduates to the labour market needs, that is, there is a gap between the demand for and the supply of technical graduates into the market. Entrepreneurship education is to help create the skills that the graduates need to close this gap. The trade subject, Radio, Television and Electronic Work is among the technical college curricula devoid of core entrepreneurship contents [11] . Entrepreneurship skills will facilitate the deployment of the technical skills in Radio, Television and Electronic Work trade to markets. Therefore, integration of the curriculum can be seen as a creative and assertive strategy for job creation and wealth generation.

\section{OBJECTIVE OF THE STUDY}

The main objective of the study is to determine the perceptions of stakeholders for integrating entrepreneurship skills components with Radio, Television and Electronic Work trade curriculum contents.

\section{RESEARCH QUESTION}

What are the perceptions of stakeholders for integrating entrepreneurship skills components across Radio, Television and Electronic Work trade curriculum contents?

\section{LITERATURE REVIEW}

Literature is reviewed on the stages of lifelong learning, entrepreneurship skills, and Radio, Television and Electronic Work trade curriculum.

Curriculum can be seen as an abridge of interdisciplinary topics from different disciplines rearranged around overlapping concepts and emergent patterns or designs. Curriculum could blend two or more major disciplines by locating and merging overlapping skills, concepts, and attitudes in them. Curricula integration evolves by extracting related ideas out of subject matter content. Curriculum planners make matches among related concepts to produce comprehensive meanings. Curricula integration is highly suitable in middle and secondary schools [3] . Entrepreneurship skills and Radio, Television and Electronic Work trade contents happened to possessed interdisciplinary topics that could be merge according to concepts and skills overlap for lifelong learning. Therefore, integrating curricula is desirable in order to help students and school leavers become entrepreneurs in Radio, Television and Electronic Work trade.

[12] , in his study, utilized the five (5) stages for lifelong learning (adopted from the Consortium for Entrepreneurship Education) to integrate curriculum. A summary of the stages is discussed below.

Stage 1 - Basics: At this stage understanding the basics of our economy, the career opportunities available, and the need to master basic skills to be successful in a free market economy. Radio, Television and Electronic Work trade students, in technical colleges, should be exposed to various experiences and activities of business ownership.

Stage 2 - Competency Awareness: Here Radio, Television and Electronic Work trade students will learn to business communication methods and discover problems from the small business owner's point of view. This is needed in career and technical education where learning technical (Radio, Television and Electronic Work) as well as entrepreneurship competencies is vital. For instance, teaching constructional features of decoder in communication as technical theory and sales and services of decoder as entrepreneurship skills.

Stage 3 - Creative Applications: At this stage, students in Radio, Television and Electronic Work trade are supposed to apply entrepreneurship skills learnt in technical college in the world of work without great difficulties to be encountered about starting and running a business. Many businesses become successful if individuals have the ability to translate business theory into practice; ability to translate professional courses creatively into specific issues of occupational skills in order to solve business problems. At this point, job training is certified and trainees cross over to the individual or group businesses.

Stage 4 - Start Up: After students graduated they would have time to gain job experience or further their education. There is also the need to understand business ideas and policies for starting a small business. Source of finance is another aspect which need to be addressed. Starting a new business requires funding which might be obtained from family and friends or non-governmental organizations for proper start-up.

Stage 5 - Growth: The next phase after start-up is business establishment and growth, all things being normal. Business growth occur through expansion of the existing business before saturation point is reached. However, after a business entity reached its peak, the declining process may begin; that is the business starts losing bearing by experiencing market troubles. Business owners should not hesitate to seek help from support-groups who can assist the entrepreneur in recognizing potential problems and how to deal with them as they arose.

\section{Entrepreneurship Skills}

It is no longer enough to train students for a career. Technical colleges must prepare students for the dynamism in the world of work [13] . Entrepreneurship as a concept has so many definitions. It could mean self-employment [14] ; as the ability of an individual to take financial risk in a business venture [15]; or capability to create goods and services demanded by society [16] . While entrepreneurship skills refer to those skills needed in a system of starting, operating, and sustaining a business within the scope of a market where opportunities exist for exploitation. For example, awareness, recognizing opportunities, creating value, and customer relations [17] \& [18].

It has been indicated by [5] that the philosophy of entrepreneurship education is to equip every technical college graduate with functional trade and entrepreneurship skills, relevant attitudes including ethical, civic, and moral 
values needed for job creation, poverty eradication and wealth generation. Moreover, [20] stated that among the objectives of entrepreneurship education is developing students' skills, know-how, experience, attitudes, resourcefulness, and network required to pursue different entrepreneurial opportunities. Therefore, issues for consideration arose as follows: What entrepreneurship contents are to be integrated into the Radio, Television and Electronic Work trade curriculum? How to integrate entrepreneurship contents into the Radio, Television and Electronic Work trade curriculum? How much time or period can be allocated to cover the content of Radio, Television and Electronic Work curriculum?

[21], [22] , [18], [17], [23], and [24] pointed out that components of entrepreneurship skill areas to be considered for integration into trades curricula include: (a) Entrepreneurial awareness (b) Qualities of an entrepreneur (c) Self and paid employment (d) Ethics in life and business (e) Business ideas and opportunities (f) Business plan (g) Starting and operating a business, and (h) Business report.

Researchers like [25] and [26] also indicated that another important aspect for consideration is the teaching and evaluation strategies for the integrated curriculum. Teaching strategies may include the following; (a) Practical project method (b) Workshop method (c) Exploration or Discovery method (d) Demonstration method (e) Field trip method (f) Simulation or Role play method (g) Case study approach (h) Career talk or Resource person's presentation (i) Question and answer (Socratic) method (j) Discussion method, and (k) Lecture method. While evaluation strategies could be; (a) Test (Written or Oral) (b) Continuous assessment (CA) (c) Examination (d) Assignment (e) Assessment of student's project (f) Student's report on activities done.

Table 1: Components of Entrepreneurship Skills Contributed by Scholars

\begin{tabular}{|c|c|c|}
\hline $\mathbf{S} / \mathbf{N}$ & Author & $\begin{array}{l}\text { Component } \\
\text { Entrepreneurship Skills }\end{array}$ \\
\hline 1. & $\begin{array}{l}\text { Deveci \& } \\
\text { (2017) }\end{array}$ & Business ideas \& opportunities \\
\hline 2. & $\begin{array}{lr}\text { Kalimasi } & \& \\
\text { Herman } & (2016) \\
\text { and Orji (2013) }\end{array}$ & $\begin{array}{l}\text { Qualities/characteristics } \\
\text { entrepreneurs, Self \& paid } \\
\text { employment }\end{array}$ \\
\hline 3. & $\begin{array}{l}\text { Obiama (2015), } \\
\text { Orji (2013), \& } \\
\text { Ramirez, Orejuela, } \\
\text { and Vargas (2010) }\end{array}$ & Entrepreneurial awareness \\
\hline 4. & $\begin{array}{l}\text { Nwosu (2017) \& } \\
\text { Orji (2013) }\end{array}$ & Ethics in life \& business \\
\hline 5. & $\begin{array}{l}\text { Obiama (2014) \& } \\
\text { Harris (2006) }\end{array}$ & Business plan, Business report \\
\hline 6. & $\begin{array}{l}\text { Obiama (2015) } \\
\text { \&Harris (2006) }\end{array}$ & Starting \& operating a business \\
\hline
\end{tabular}

Radio, Television and Electronic Work Trade Curriculum

Radio, Television and Electronic Work trade is one of such career education courses that is being offered in Nigerian technical colleges. The curriculum at National Technical Certificate (NTC) level is designed to produce skilled craftsmen who shall be self-employed in local industries. The course contained seven different modules which include: Basic Electricity (CEI 11), Electronic Devices and Circuits (CEI 12), Radio Communication Systems (CRT 13), Radio and Audio Frequency Amplifier (CRT 14), Satellite Transmission and Reception (CRT 15), Television (CRT 16) and Workshop Practice and Maintenance (CEI 17). The course is intended to give students insight into the world of Radio, Television and Electronic Works; improve their attitude towards the servicing, maintenance and repairs of Radio, Television and electronic equipment and enable them to appreciate the relationship between science and technology [11].

In the context of this study Radio, Television and Electronic Work trades in Nigerian technical colleges will begin a new era due to the fact that government is in dire need to address socio-economic challenges such as youths restlessness, poverty and unemployment. Therefore, policies, reforms, and strategies should aim at reviving the economy and tackle other challenges of national development. Prominent among the strategies is the National Economic Empowerment Strategy (NEEDS) which was formulated in 2004. The main objective of NEEDS is to use education to empower the citizens. Thus, in Nigeria, in addition to inculcating functional literacy and numeracy skills in school leavers, education is expected to address the challenges of youths' restlessness and unemployment by promoting the specific goals of value re-orientation, wealth creation, poverty eradication and employment generation. Among the reasons attributed to youths' restlessness and unemployment in Nigeria was lack of relevant work skills and competencies in young school leavers due to absence of effective entrepreneurial skills in schools' curricula that would prepare them for 21st century world of work [9] . In the present study, a novel and unique approach for integrating entrepreneurship skills into Radio, Television and Electronic Work trade curriculum in Nigerian technical colleges is conducted.

\section{METHODOLOGY}

The research methodology describes the procedures followed in conducting the study and are discussed under the following sub-headings:

\section{A. Research Design}

Intrinsic case study design is used to conduct the present study. An intrinsic case study is a type of qualitative study which develop a comprehensive understanding of a particular case or processes [22] . [27] stated that intrinsic research design is also used to study an occupation, department, organization, specific groups or individuals where exploration of the case is led by the desire and interest to know more about the uniqueness of the case under study. However, intrinsic case study is exploratory in nature and preparation about whom to talk with, where to collect data, and which events to observe are very important. The structure of the case report is mainly determined by the stories and experiences obtained from data collected. 


\section{B. Area of the Study}

Government Technical College Kano (GTCK) and Government Technical College Malali (GTCM) were purposely selected as the area of the study and the reason for their selection is that they were among the oldest and wellstocked technical colleges that specialize in the training of Radio, Television and Electronic Work trade students in North-Western Nigeria.

\section{Sample and Sampling Technique}

The sample population of the present study is shown in table 2 .

Table 2: Sample Population of the Study

$\begin{array}{llll}\text { S/No States Colleges } & \begin{array}{l}\text { Number of } \\ \text { Curriculu }\end{array} & \text { Entrepreneurshi } \\ & & m \text { Planners } & \text { p Teachers }\end{array}$

\begin{tabular}{lllll}
\hline 1. & Kadun & GTC & 3 & 3 \\
a & Kano & $\begin{array}{l}\text { GTC } \\
\text { Kano }\end{array}$ & 4 & 4 \\
3. & Total & & 7 & 7 \\
4. & $\begin{array}{l}\text { Grand } \\
\text { Total }\end{array}$ & & & \\
& & &
\end{tabular}

Seven (7) trade curriculum planners and seven (7) entrepreneurship teachers ( 3 from Kaduna and 4 from Kano) were purposely selected as the sample of the study, making a total of fourteen (14). Curriculum planners in the context of this study refer to substantive and previous heads of Radio, Television and Electronic Work programmes who worked in technical colleges and were selected due to their rich experiences in the field. The choice of 14 participants is in line with the recommended sample size ranging from five to twenty-five for a phenomenological study [27]. The strategy for selecting sample was purposive sampling. Purposive sampling is viewed as judgemental sampling to represent the population of interest without sampling at random, deciding what to be known by an individual or groups, and setting out to find persons available and willing to participate in a study by providing information based on their knowledge or experience [29].

\section{Instrumentation}

Semi-structured interview was used as the tool for data collection in the qualitative study. The interview protocol was subjected to face and content validation using three experts. The validates were: one entrepreneurship teacher from Government Commercial College Kano, one curriculum planner from National Board for Technical Education, Kaduna, and one electronic business owner from Kano. Member checking and peer debriefing were used to determine the reliability of the interview protocol. Member checking means submitting the interview transcript back to the participants in order to review and confirm the credibility of the data and accuracy of the narrative descriptions [30]. This authenticates and improves the quality of the recorded interview data. In the present study, peer debriefing means appraisal of the interview data by an expert in a particular field of study with rich experience in qualitative research. Peer debriefing is done to establish reliability of the interview data or phenomenon under investigation in qualitative research [28]. The written comments, suggestions, and corrections of the experts were used to update the instrument.

The interview gathered information on perceptions for integrating entrepreneurship skills across Radio, Television and Electronic Work trade curriculum in Nigerian technical colleges from two strata of samples; entrepreneurship teachers and curriculum planners. The data received from the participants were transcribed verbatim, coded and analyzed by using Nvivo version 12 . The data were also translated into bar chart using percentages to illustrate the level of acceptability.

Another tool for data collection used in the context of this study was document analysis on components of entrepreneurship skills required for integration into Radio, Television and Electronic Work curriculum. The aim is to gather information on policy context for integrating entrepreneurship skills into Radio, Television and Electronic Work trade curriculum in technical colleges of Nigeria. In addition, the provisions of the Federal Republic of Nigeria (FRN) on two policy documents on entrepreneurship skills in technical colleges were analysed. The policy documents were the National Policy on Education (NPE, 2014) and National Economic Empowerment and Development Strategy (NEEDS, 2004) sourced from [31].

\section{E. Scope of the Study}

This study essentially investigates integrating entrepreneurship skills into Radio, Television and Electronic Work trade curriculum in technical colleges in NorthWestern Nigeria. The investigation mainly relied on perceptions of stakeholders (entrepreneurship teachers and trade curriculum planners). The study is limited to Radio, Television and Electronic Work trade curriculum alone and two technical colleges in North-Western Nigeria have been used.

\section{FINDINGS}

The researchers considered holistic integration of entrepreneurship skills into Radio, Television and Electronic Work trade curriculum in the two colleges based on policy context and perceptions of stakeholders. The stakeholders used were entrepreneurship teachers and Radio, Television and Electronic Work curriculum planners.

\section{A. National policy context of entrepreneurship skills in} technical colleges.

Document analysis shows that there is specific national policy for integrating entrepreneurship skills in technical college courses including Radio, Television and Electronic Work trade curriculum. The Federal Republic of Nigera (FRN, 2014) exclusively stated that the curriculum for each trade shall consist of entrepreneurial training by establishing and operating a production unit for on-the-job training of students and for commercial activities for sustainable socioeconomic development (NPE,

p. 25). It can be pointed out 
here that certain technical trades deal greatly in services rather than production, for instance Radio, Television and Electronic Work and Electrical Installation trades. Workshops are the usual training places for learning in these trades rather than production units. Hence, the students in Radio, Television and Electronic Work and Electrical Installation trades are missing the components of entrepreneurship skills in their training. A good avenue for learning entrepreneurship skills for the students is curriculum integration where the components of both entrepreneurship skills and Radio, Television and Electronic Work trade will be embedded in a single document (integrated curriculum).

Another policy document, National Economic Empowerment and Development Strategy (NEEDS, 2004), stressed the empowerment of young people through educational processes in order to promote sustainable socioeconomic development by wealth creation, employment generation, and reduction of poverty. But NEEDS (2004) did not exclusively stated how educational processes will go about to achieve the empowerment of young people, especially students in technical colleges. In fact, it can be opined here that technical colleges were relegated to the background in this policy. Therefore, integrating entrepreneurship skills into Radio, Television and Electronic Work trade curriculum will be a good way to promote wealth creation, employment generation, and reduction of poverty in Nigeria.

B. Perceptions of stakeholders on entrepreneurship skills needed for Radio, Television and Electronic Work trade curriculum in technical colleges.

Some sample of excerpts (interactions) from the interview is reported in table 3 below using the following codes for representations: $\mathrm{R}=$ Researcher; $\quad \mathrm{Pe}=$ Entrepreneurship teachers as participants; and $\mathrm{Pc}=$ Curriculum planners as participants.

Table 3: Excerpts from the interview.

\begin{tabular}{lll}
\hline QUESTION (R) & RESPONSE (Pe) & RESPONSE (Pc) \\
\hline Could you please, tell me whether I cannot exactly say but I think the & No. the Radio, Television and \\
entrepreneurship skills are taught to students learn economics. & $\begin{array}{l}\text { Electronic Work trade curriculum does } \\
\text { not address entrepreneurship skills in }\end{array}$ \\
students in Radio, Television and & technical colleges.
\end{tabular}

colleges in north-western Nigeria?

Do you think it is important to Yes, it will help the students to form integrate entrepreneurship skills better work skills.

alongside Radio, Television and

Electronic Work trade curriculum?
Of course, the students will expand their skill horizons and the teachers as well. Though pedagogy of teaching may be adjusted or changed.

Ethics in business. Recognizing business opportunities.

Creating business ideas.
Can you briefly, itemize the Personal char
ntrepreneurship skills desirable for entrepreneurs.

integration into Radio, Television and Sales and marketing. Business skills Electronic Work trade curriculum such as report writing.

based on your understanding of the trade?

What are the components of Self and paid employment, business entrepreneurship skills required for ideas and opportunities.

Radio, Television and Electronic

Work trade?

How knowledge of entrepreneurship skills can contribute to Radio, Work graduates can establish $\begin{aligned} & \text { Television and Electronic } \\ & \text { graduates' employment? }\end{aligned}$
earn some money. They may link-up with master apprentice when need arises. 
Sir, can you explain how Variety of teaching approaches has Experiential learning, visit to colleges implementation of the integrated to be adopted in the classroom. by expert technicians and business curriculum can be achievable, if done? Another method is collaboration owners to lecture the students, between Radio, Television and apprenticeship with Radio, Television and Electronic Work students and local Electronic Work technicians and business repairers so as to service electronic owners will greatly help the students to fit apparatus for financial gains. into market. More important is the Commission can be given to college retraining needs of trade teachers.

authority who provided tools and

materials for learning. Donor supports

from philanthropists is another way.

Different interpretations of entrepreneurship skills among stakeholders will definitely influence its integration into core curriculum. The findings in this study shows that a range of perceptions and understandings of entrepreneurship skills span across business skills, innovations, personality characteristics, self and paid employment, ethics in life and business, business ideas and opportunities, starting and operating a business, business plan and report. To some extent, the perceptions expressed by stakeholders were not mutually exclusive. Although the words used by entrepreneurship teachers differ from those used by curriculum planners, the meaning seemed to be the same. For example, self-employment is regarded as private practice and a supplementary income-generating venture for people with permanent and pensionable employment. The reasons for such differences may lie in the context of age, the presence or absence of an entrepreneurship policy, and the strategic approaches to college management. Moreover, re-training of teachers and donor supports from governmental and non-governmental agencies were perceived as complementary factors to effective implementation of entrepreneurship skills in technical colleges. Finally, the differences in understanding obviously results in an ambiguity about what entrepreneurship skills should entail and hinders consensus about appropriate implementation strategies across technical curricula.

\section{DISCUSSION}

Entrepreneurial awareness is perceived as a component of entrepreneurship skills by entrepreneurship teachers $(50 \%)$ and Radio, Television and Electronic Work curriculum planners $(50 \%)$. This finding is supported by [18], [17] \& [16] who mentioned creating entrepreneurship awareness as a skill in their respective works.

Qualities of entrepreneurs is recognized by entrepreneurship teacher (50\%) and Radio, Television and Electronic Work curriculum planners (43\%) as a component of entrepreneurship skill. Despite silence of $7 \%$ from participants, it could still be considered as a component since majority accepted personal traits as entrepreneurship skill. [22] and [17] buttressed this finding because they included personal characteristics of entrepreneurs as skill. In addition, [22] and [17] also confirmed self and paid employment to be a component of entrepreneurship skill. In this study, entrepreneurship teachers (50\%) and Radio, Television and Electronic Work curriculum planners (43\%) perceived self and paid employment as entrepreneurship

skill. 7\% were did not accept self and paid employment as component of entrepreneurship skills.

It was discovered in this study that entrepreneurship teachers (43\%) and Radio, Television and Electronic Work curriculum planners $(36 \%)$ agreed that ethics in life and business is an entrepreneurship skill. Though, $21 \%$ of participants were silent on ethics in life and business. It could be concluded that ethics in life and business is an entrepreneurship skill because it is advocated by [7] and [17] .

Business ideas and opportunities were totally accepted as a component of entrepreneurship skill by both entrepreneurship teachers (50\%) and Radio, Television and Electronic Work curriculum planners (36\%). $14 \%$ of participants from curriculum section did not advocated for it. This finding is supported by [21] in their study.

Starting and operating a business is also identified as entrepreneurship skill by entrepreneurship teachers (43\%) and Radio, Television and Electronic Work curriculum planners $(36 \%)$. Although, $21 \%$ of participants in the study were silent on this finding. It could be safely accepted because [18] \& [24] reported starting and operating a business as an entrepreneurship skill.

Business plan is discovered as entrepreneurship skill as perceived by entrepreneurship teachers (50\%) and Radio, Television and Electronic Work curriculum planners (43\%); having stakeholders silence of $7 \%$. Whilst Business report has percentage agreement of $50 \%$ and $36 \%$ by teachers and Radio, Television and Electronic Work curriculum planners respectively. Stakeholders silence of $14 \%$ is obtained on business report in the study. Despite the $14 \%$ silence, it could be accepted that business report form a part of entrepreneurship skills as observed by [19] and [24] in their studies.

Finally, donor supports and retraining needs of Radio, Television and Electronic Work trade teachers were perceived as complimentary factors for enhancing the implementation of integrated curriculum such as entrepreneurship skills and Radio, Television and Electronic Work trade curriculum. Donor supports has $43 \%$ acceptance from teachers and $43 \%$ acceptance from curriculum planners. $14 \%$ of the participants did not proclaimed donor support as a component of entrepreneurship skills. While retraining need of Radio, Television and Electronic Work 
trade teachers possessed $43 \%$ acceptance from teachers and $50 \%$ acceptance from Radio, Television and Electronic Work curriculum planners. $7 \%$ of participants did not announce it. This finding is contrary to the components of entrepreneurship skills explored from the literature. Therefore, donor supports and retraining needs of teachers can be regarded as complimentary factors towards effective implementation of integrated curriculum. Perceptions of stakeholders on components of entrepreneurship skill is shown in figure 2 below.

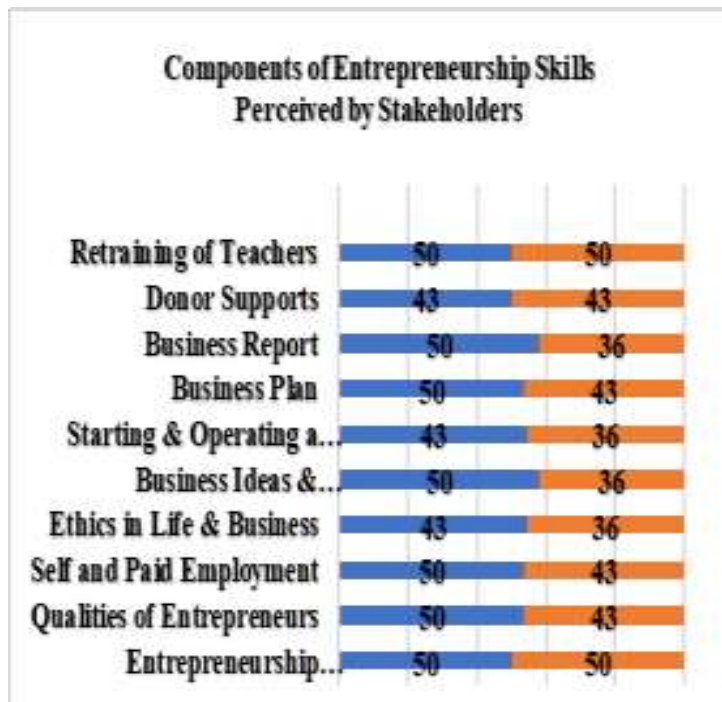

$0 \% \quad 20 \% \quad 40 \% \quad 60 \% \quad 80 \% \quad 100 \%$

\section{-Entrepreneurship Teachers $=$ RTEW Curriculum Phuners}

\section{Fig. 2: Bar chart illustrating components of} entrepreneurship skill.

Previous studies that tracked graduates' employment after leaving college mostly assessed the quality of academic programmes and explored employers' expectations in Nigeria. The studies found out that declining number of selfemployed graduates compared to graduates employed in public and private sectors is on the increase and majority of graduates prefer salaried employment. Therefore, national policies should aim at integrating entrepreneurship skills across technical disciplines, this suggestion does not negate the role and importance of business ventures but also highlights the need to expand the horizon of entrepreneurial mind-sets for diverse employment options.

\section{CONCLUSION}

The study explored Nigerian National Policy on Education (NPE) and the perceptions of stakeholders on integration of entrepreneurship skills into Radio, Television and Electronic Work trade curriculum using two technical colleges in Nigeria. It can be concluded that provision for entrepreneurial training in Radio, Television and Electronic Work trade curriculum exists in the policy document but it is non-existent in practice. While stakeholders' perceptions of entrepreneurship skills have great influence on the desirability to integrate and implement entrepreneurship skills in Radio, Television and Electronic Work trade curriculum. Lack of synergy between the National Policy on
Education and Radio, Television and Electronic Work curriculum developers also exist because the Radio, Television and Electronic Work syllabus does not reflect

topics on entrepreneurship skills as planned for technical colleges. Such synergy is important for effective knowledge and skill acquisition that can create socio-economic development. This study intends to close the gap between the provision of the national policy and National Board for Technical Education curriculum being implemented at technical college level because college stakeholders are vaguely aware of entrepreneurship skills policy for technical colleges. This is the uniqueness of this study. Based on the findings, the researchers recommend that an approach for holistic integration of entrepreneurship skills be adopted through the syllabi to be designed by curriculum developers across technical disciplines. The activity of developing syllabi can materialize by seeking donor supports from various governmental and non-governmental organizations and organizing national workshops for curriculum development. It should also be noted that courses that are presently not perceived as part of entrepreneurship education but which have entrepreneurship orientation be formally considered as imparting entrepreneurship skills [22].

\section{REFERENCES}

1. Yousif, H. M., Shuriye, A. O., \& \& Abdallah, A., Salam, M. J. E., \& Khalifa, O. O., "Integrating Entrepreneurship into Engineering Education". International Journal of $U$ and e-Service, Science and Technology, 10(2), pp. 45-52, 2017. https://doi.org/10.14257/ijunesst.2017.10.2.05

2. Hatak, I., \& Reiner, E., "Entrepreneurship Education in Secondary", pp. 1-135, 2013.

3. Fogarty, R.,. "The mindful school: How to integrate the curricula". Palatine: Skylight, 1991.

4. International Monetary Fund, "Country statistics for Nigeria". IMF Data Mapper: IMF, 2019.

5. Federal Republic of Nigera, "National Policy on Education". NERDC: Lagos-Nigeria, 2014.

6. Vaidya, S., "Developing Entrepreneurial Life Skills. Creating and Strengthening Cntrepreneurial Culture in Indian Schools". Springer, 2006.

7. Nwosu, J. C., "Entrepreneurship education and the challenges of graduate employability in Nigeria". Basic Research Journal of Business Management and Accounts Vol. 6, 2017.

8. Oranu, R. N., "Strategies for Introducing New Curricula in West Africa". International Bureau of Education: Nigerian National Commission of UNESCO: LagosNigeria, 2001.

9. UNESCO, "Global flow of tertiary-level students". Retrieved

fromhttp://www.uis.unesco.org/Education/Pages/internati onal-student-flow-viz.aspx, 2014.

10. Bunmi, A. S. \& Taiwo, A. G., "Teachers, curriculum reform for entrepreneurship education in Nigeria: Issues and consequences". Journal of Current Studies in Comparative Education, Science and Technology, 4(2), pp. 10-21, Vol. 4, 2017.

11. National Board for Technical Education, "Radio, Television and Electronic Work Trade Curriculum". Kaduna-Nigeria, 2007. 
12. Aljohani, M. (2005). Innovation and entrepreneurship integration in education: Ohio State Model. International Journal of Teaching and Education, 3(3), pp. 1-20, 2005.

13. Idris, A., \& Rajuddin, M. R., "The Influence of Teaching Approaches among Technical and Vocational Education Teachers towards Acquisition of Entrepreneurship Skills in Kano State-Nigeria", 5(3), pp. 19-22, 2012.

14. Roberts, L. P., and Chrisman, J. J., "Under one roof: Towards a reconciliation of home-based work typologies". Journal of Small Business Entrepreneurship, 13(4), pp. 18-33, 1996.

15. Bosma, N, Acs, Z. J. Autio, E., Coduras, A., Levie, J., "Global entrepreneurship monitor, 2008.

16. Ramirez, A. R., Orejuela, A. R., and Vargas, G. M., "New perspective for the managerial entrepreneurship". International Entrepreneurship and Management Journal, 6(2), pp. 203-219, 2010.

17. Orji, S. N., "The new senior secondary education curriculum: Trade entrepreneurship". FGC Buni-Yadi, Yobe State: NERDC: Lagos, 2013.

18. Obiama, G., "Transferable skills in Nigerian senior secondary education curriculum". Beacon: Washington DC.: International Initiative for Impact Evaluation, 2014.

19. Obiama, G.,"Education in Nigeria: Meeting the post 20 Conference, 2015.

20. Hussain, M. D., Bhuiyan, A. B., \& Bakar, R., "Entrepreneurship development and poverty alleviation: An empirical review", 4(10), pp. 558-573, 2014. Retrieved from http://www.aessweb.com/journals/5003

21. Deveci, Isa \& Cepni, S., "The effect of entrepreneurship education modules integrated with science education on the entrepreneurial characteristics of pre-service science teachers". Socialinis Darbas, 15(2), pp. 56-85, 2017. https://doi.org/2029-2775

22. Kalimasi, P. J., \& Herman, C., "Integrating entrepreneurship education across university-wide curricula: The case of two public universities in Tanzania, $1999^{\prime \prime}, 2016$. https://doi.org/10.1177/0950422216666668

23. Roberts, S. J., "Infusing entrepreneurship within nonbusiness disciplines: Preparing artists and others for selfemployment and entrepreneurship". Retrieved October 4, 2018 from http://artivate.org. Journal of Entrepreneurship in the Arts, 1(2), pp. 53-63, 2013.

24. Harris, T., "Start-Up: A Practical Guide to Starting and Running a New Business". Berlin Heidelberg: New York: Springer, 2006.

25. Tumba, I., \& \& Shuaibu, H., "Strategies for Improving Students , Acquisition of Practical Skills in Electrical Installation and Maintenance Work Trade in Technical Colleges in Kano State", International Journal of Engineering and Science, 5(10), pp. 30-40, 2016.

26. Audu, R., Kamin, Y., Musta'amal, A., H., \& Saud, S., M. (2014). Assessment of the Teaching Methods that Influence the Acquisition of Practical Skills, 10(21), 3541. https://doi.org/10.5539/ass.v10n21p35

27. Durepos, G., \& Wiebe, E. (2010). Intrinsic Case Study. SAGE. Thousand Oaks.

28. Creswell, J. W., "Research design: Qualitative, quantitative and mixed methods approaches", 4th ed. Los Angeles: Sage, 2013.

29. Collins, K. M. T., Onwuegbuzie, A. J., \& Jiao, Q. G. (2007). Journal of Mixed Methods Research. https://doi.org/10.1177/1558689807299526

30. Lincoln, Y. S., \& Guba, E. G., "Naturalistic inquiry. Beverly Hills, CA: Sage, 1985.

31. World Bank, "National Economic Empowerment and Development Strategy (NEEDS)". Nigeria: IDA \& IMF: The World Bank, 2005.

\section{AUTHORS PROFILE}

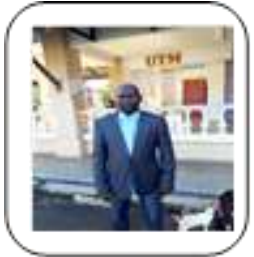

First Author Halliru Shuaibu is a native of Kano State, Nigeria. He obtained Bachelor's and Master's degree in Industrial Technology Education (Electronics) from Federal University of Technology Minna and Modibbo Adama University of Technology, Yola. Presently, he is a Doctorate student in School of Education, Universiti Teknologi Malaysia (UTM), Malaysia. He is a registered teacher and worked in technical colleges in Nigeria both at ordinary and advance levels since 2001. He also served as Chief-Examiner (GSM Subject) for National Examinations Council (NECO), Nigeria, between 2014 and 2018. He has research interest in vocational, technical, collaborative, and entrepreneurship education. 